\title{
An Analysis on the Use of Derivational and Inflectional Morphemes in English Song Lyrics on Maher Zain's “Forgive Me” Album
}

\author{
Yuli Purwanti \\ Pendidikan Bahasa Inggris STKIP Nurul Huda Sukaraja \\ Yulipurwanti42641@gmail.com
}

\begin{abstract}
The primary thing to be learned in mastery a language is word. Word is dealing with morphology, because morphology influences spelling, reading comprehension, and vocabulary. In the way of understanding the meaning of vocabulary, language users need to learned morphology, especially derivational and inflectional morphemes. This study was designed to identify the derivational and inflectional morphemes and the functions of each derivational and inflectional morphemes are used on Maher Zain's "forgive me" album. The result of this study are; (1) There were 13 derivational morphemes and 76 inflectional morphemes, and (2) The functions of every morphemes used on Maher Zain's "forgive me" album, consist of function as adjective, plural, verb, noun, and adverb.
\end{abstract}

Kata kunci: An Analysis, Morphemes, Lyrics.

\section{INTRODUCTION}

According to Siahaan (2008:1), language is used by humans as a tool of their communication. Meanwhile, language is not only use to communicate, but also to express an existence, opinions, ideas, concepts, and even speaker's feelings. Those are the reasons why language has important role in human life. Except it, by the use of language we are able to deliver our message with others and we can make an interaction with others particularly in our position as the member of society (Risdianto, 2013: 1). By means of it, language is social means of communication.

Based on Bauer (2012:3), linguistics is the meaning of the word ' relating to language, as well as the word meaning 'relating to linguistics. It have somemeaning that linguistics is concerned with the relation of knowledge about language which has important role for branches of it is own. Linguistic has some branches, they are phonetic, phonology, morphology, syntax, pragmatic, and semantic. In this study, the writer focused on morphology.

According to Rafold (2006:59), the branch of linguistics that is concerned with the relation between meaning and form within word is known as morphology. In the other word, according to Aronoff and Fudeman (2011:2), morphology also defined as the science that studies about morphems. Morphemes is the smallest unit meaningful with a grammatical function. According to Lieber (2016:2), there are two types of morpheme: free morpheme and bound morpheme. A free morpheme is one morpheme that may stand alone in a language, without requiring any other morphemes. For instance, cat, book, and happy can occur on its own as a word. Whereas, bound morphemes are never words by themselves but are always parts of words. These affixes are bound morphemes and they may attach at the beginning, the end, in the middle, or both at the beginning and end of a word.The set of morphemes that are on bound category are divided into two types: namely derivational and inflectional morphemes.

A derivational morpheme is one that added to a base to form a new word that differs in its part of speech classification (Kolanchery, 2015). When derivational morpheme is added to the base of a word, it can result into a change in the part of speech or grammatical category of that word. For instance, when the suffix -ness is added to the adjective 'happy', the adjective 'happy' become the noun 'happiness'. While, inflectional is a morpheme that indicates some kind of grammatical relationship (Kracht, 2007:4). For example, the -s morpheme attached to the word likes indicates the present tense for singular person.

Related the statement above, learning about morpheme is very important. Because of the primary 
thing to be learned in mastery a language is word. Word is dealing with morphology, because morphology influences spelling, reading comprehension, and vocabulary. In the way of understanding the meaning of vocabulary, language users need to learned morphology, especially derivational and inflectional morphemes.

Based on the explanation above, the writer was interested to conduct research entitles "An Analysis on the Use of Derivational and Inflectional Morphemes in English Song Lyrics on Maher Zain's "Forgive Me" Album.

\section{Concept of Linguistic}

According to Cook (2002:20), "Linguistics is the academic discipline concerned with the relation of knowledge about language to decision making in the real world". Its mean that, linguistics is the study about language. In another word, linguistics is concerned about language which has important role for branches of it is own.

Bauer (2012:3), state that linguistics is the meaning of the word 'relating to language' as well as the word meaning 'relating to linguistics'. That is why when we learned about language then we should learn about linguistic too. Because they have close relation to language and both of them can not be separated.

In another word, the goals of linguistic study is not only about study language but also about another theory. According to Carnie (2002:4), linguistic is also a branch of cognitive science. Cognitive science is a term for a group of disciplines that have the same ambiguity goal, defining and analyzing human being's ability to think.

\section{Morphology}

Morphology consists of two morphemes, morph + ology. The suffix -ology means a branch of knowledge. Therefore, morphology is the branch of knowledge concerned with word formation. Fromkin, Rodman, and Hyams, (2011:33) "explained that the study of the internal structure of words, and of the rules, by which words are formed, is morphology".

Morphology research aims to describe and explain the morphological patterns of human languages. According to Yule (2010:67), morphology is the study focusing more on forms in language rather than depending on identifying words. Morphology processes fulfill two primary purposes: to create new words in a language and to modify existing words.

One of the functions that Morphology does is word formation. Word formation deals with the creation of new words by various morphological mechanisms such as compounding, affixation, derivation, inflection, truncation, and segmental, tonal alternations, and so on (Booij, 2005:13).

\section{Concept of Morpheme}

Haspelmath and Sims (2010:2) defines that morpheme is the smallest meaningful constituents of words that can be identified. Furthermore, the term morpheme is used to refer to the smallest, indivisible units of semantic content or grammatical function which word are created (Katamba \& Stonham, 2006:328).

In fact, a single word can carry a number of morphemes. For instance, the word unlovable consists of three morphemes, the word 'un' which makes the word to be negative form, "love" which means get strong feeling of deep affection, and 'able' which means the ability to do something.

Stem is a part of a word which inflectional affixes attach to, for example, in the word un-lovable, the word lovable is a stem (Plag, 2003:22). Other affixes can be added to a stem to form a more complex stem, for example, in the word unlovable, the word unlovable is a complex stem.

\section{Types of Morpheme}

According to Lieber (2016:2), there are two types of morpheme; free morpheme and bound morpheme. 


\section{1) Free Morpheme}

A free morpheme is one morpheme that may stand alone in a language, without requiring any other morphemes (Lieber, 2016:2). For instance, cat, book, and happy can occur on its own as a word; those words do not have to be attached to another morpheme. A free morpheme is categorized into two: open class (content words) and closed class (function words). Open class denote concepts such as objects, actions, attributes, and ideas that the readers can think about as children, build, beautiful, and seldom. However, closed class specifies grammatical relations and has little or no semantic content.

\section{2) Bound morpheme}

According to Lieber (2016:3), a bound morpheme is a morphological element that can only appear as a proper subpart of a word, such as -ish, -ness, -ly, and un. Bound morphemes are never words by themselves but are always parts of words. These affixes are bound morphemes and they may attach at the beginning, the end, in the middle, or both at the beginning and end of a word. The set of morphemes that are on bound category are divided into two types: namely derivational and inflectional morphemes.

\section{a. Derivational morphemes}

A derivational morpheme is one that is added to a base to form a new word that differs in its part of speech classification (Kolanchery, 2015:5). When derivational morpheme is added to the base of a word, it can result into a change in the part of speech or grammatical category of that word. For instance, when the suffix -ness is added to the adjective 'happy', the adjective 'happy' become the noun 'happiness'. Bound morphemes like -ify, -cation, and-arian are called derivational morpheme. When they are added to a base, a new word with a new meaning is derived. The form that results from the addition of derivational morpheme is called a derived word. Moreover, when a base is added by derivational morpheme, it changes meaning.

There are some processes of derivational morpheme according to Fromkin, Rodman, and Hyams (2011:45):

\section{Noun to adjective}

$$
\begin{aligned}
& \text { e.g. : } \text { boy }+ \text { ish }=\text { boyish } \\
& \text { health }+ \text { ful }=\text { healthful } \\
& \text { alcohol }+ \text { ic }=\text { alcoholic }
\end{aligned}
$$

\section{Verb to noun}

$$
\begin{aligned}
& \text { e.g. : create + ion = creation } \\
& \text { sing }+ \text { er }=\text { singer } \\
& \text { predict }+ \text { ion = prediction }
\end{aligned}
$$

\section{Adjective to adverb}

e.g. : exact + ly = exactly

\section{Noun to verb}

$$
\begin{aligned}
& \text { e.g. : moral }+ \text { ize = moralize } \\
& \text { glory }+ \text { ify = glorify }
\end{aligned}
$$

\section{Adjective to noun}

$$
\text { e.g. : free }+ \text { Dom }=\text { freedom }
$$
specific + ity $=$ specificity

\section{Verb to adjective}

e.g.: read + able $=$ readable create + ive $=$ creative

\section{Adjective to verb}

$$
\begin{gathered}
\text { e.g.: ideal }+ \text { ize }=\text { idealize } \\
\text { en }+ \text { rich }=\text { enrich }
\end{gathered}
$$

Derivation can also occur without any change of form, such as 'telephone' (noun) and to 'telephone' (verb). This is known as conversion or zero derivation. Below are other examples of derivation without changing grammatical classes (Fromkin, Rodman, \& Hyams, 2011: 45):

1. Noun to Noun

$$
\begin{aligned}
& \text { 1. Noun to Noun } \quad \text { Friend + -ship = friendship, } \\
& \text { human }+ \text {-ity = humanity, } \\
& \text { king }+ \text {-dom = kingdom, } \\
& \text { dis + advantage = disadvantage, } \\
& \text { un + employment = unemployment } \\
& : \begin{array}{l}
\text { Un + do = undo, } \\
\text { re }+ \text { cover = recover, }
\end{array}
\end{aligned}
$$


3. Adjective to Adjective : Pink + -ish= pinkish,

$$
\begin{aligned}
& \text { dis- }+ \text { believe }=\text { disbelieve, } \\
& \text { auto }+ \text { destruct }=\text { autodestruct }
\end{aligned}
$$

$$
\begin{aligned}
& \text { il- + legal = illegal, } \\
& \text { in- + accurate = inaccurate } \\
& \text { un- + happy = unhappy }
\end{aligned}
$$

Katamba and Stonham, (2006:44) explained that derivation morpheme can be either prefixes or suffixes, whereas inflectional affixes are only suffixes.

b. Inflectional morphemes

According to Kracht (2007:4), inflection is a morpheme that indicates some kind of grammatical relationship. For example, the $-s$ morpheme attached to the word likes indicates the present tense for singular person. The key point about inflection is that applying it never gives a new word class, but only a different form of the same word (Hippisley \& Stump, 2016:23). For instance, when adding certain affixes to the word write, producing forms like writes, writing, and written, those words do not get any new word class, but only grammatically distinct forms of the same words. Another example is the word books; it consists of a free morpheme book and a suffix $-\mathrm{s}$. The bound morpheme $-\mathrm{s}$ does not change the syntactic category of the morpheme book. It only gives grammatical meaning which shows that the word books is plural. However, the word class is still the same in which the noun book when added a suffix $-\mathrm{s}$ is still a noun.

According to Fromkin, Rodman, and Hyams (2011:47), modern English has eight inflectional affixes to indicate the following:

1. $-s$ third-person singular, e.g.: She wait-s at home.

2. -ed past tense, e.g.: She wait-ed at home.

3. -ing progressive, e.g.: She is eat-ing the donut.

4. -en past participle, e.g.: Mary has eat-en the donuts.

5. $-s$ plural, e.g.: She ate the donut-s.

6. -'s possessive, e.g.: Disa's hair is short.

7. -er comparative, e.g.: Disa has short-er hair than Karin.

8. -est superlative, e.g.: Disa has the short-est hair.

\section{Function of Morphemes}

The function of certain derivational morpheme $s$ is to create new base forms (new stems) that other derivational or inflectional affixes can attach to (Kolanchery, 2015:162). There are the functions of derivational morpheme that will be analyzed.

\section{a) Function of Derivational Morpheme}

1. Noun formation

Noun formation is a kind of derivational process which is formed by the change of current part of speech into noun formation. Noun formations consist of:

a. Verb into Noun -ment) = Government (noun)

b. Adjective into Noun For example: Opportune (Adjective) + (-ity) = Opportunity (Noun).

2. Verb formation

Verb formation is a kind of derivational process which is formed by the change of current part of speech into verb formation. Verb formations consist of:

a. Adjective into Verb For example: Off (Adj) $+(-e r)=$ Offer (Verb) .

b. Noun into Verb For example: Courage (Noun) $+(-$ ed $)=$ Discouraged (verb).

3. Adjective formation

Adjective formation is a kind of derivational process which is formed by the change of current part of speech into adjective formation. Adjective formations consist of:

a. Verb into Adjective 
For example: Understand (Verb) $+(-$ able $)=$ Understandable (Adj)

b. Adverb into Adjective

For example: Ever (Adv) $+(-y)=$ every $($ Adj $)$

c. Noun into Adjective

Home (noun) $+(-$ less + -ness $)=$ Homelessness $($ Adj $)$

4. Adverb formation

Adverb formation is a kind of derivational process which is formed by the change of current part of speech into adverb formation. Adverb formations consist of:

a. Adjective into Adverb

For example: Probable (Adj) $+(-\mathrm{ly})=$ Probably (Adv).

b. Noun into Adverb

For example: consideration (Noun) $+($ ly $)=$ Considerably (Adverb)

c. Verb into Adverb

For example: $(A-)+$ Round (verb) $=$ Around $(A d v)$

\section{b) Function of Inflectional Morpheme}

An inflectional morpheme indicates certain grammatical properties associated with nouns and verbs, such as gender, number, case and tense. In English, the inflectional morphemes are all suffixes. The suffix $-s$ which indicates either possession or plurality in nouns, is an inflectional morpheme; the suffix -ed, which is used to add to the verbs for the formation of past tense is another one (Kolanchery, 2015:164). Inflectional affixes modify a word's form and change the grammatical subclass of the word. The examples are boys and played i.e. adding $-\mathrm{s}$ to form plurality and -ed for the past tense respectively. It may also be remembered that an inflectional suffix comes at the end of the word and no other suffix can be added to the word further. It does not change the part-of-speech of the word like derivational affixes.

\section{Concept of Song}

according to Moeliono (2007: 624) song is a variety of rhythmic sounds. Song is is the result of relationship art from sound and language arts, as sound artworks involve the melody and voice color of the singer.

Moreover, "Song is a short poem or number of verse set to music and intended to be song", (Homby, 1980:822). It means song is a deliver words or sentence which is composed by rhytm and rhyme to expresses the feeling to claims emotional place in music and poem.

\section{Definition of Song Lyrics}

Song lyrics are expressions of song writer from within about something that has been seen, heard or experienced. It is supported by Bull (2008:423), stated that a song contains language exposition used by a composer to express her/his feeling, thought, and willing.

Song lyric have a message which contained and delivered depending on how the composer put the words in the lyrics (Bertoli-Dutra and Bissaco, 2006: 1053). Moreover, Wellek and Warren (1989:14-15) stated that By song lyric's a message which oral or written has function to create an imagination for the listener and has multiple meaning

Therefore, based on the opinion above, it can be concluded that song lyric is expressing direct personal feelings, of or for singing, words of a song and lyrical is expressing strong emotion in an imaginative way.

\section{METHODOLOGY}

Qualitative research is a type of scientific research. In this study, the writer used descriptive qualitative method to analyze the data that indicated to derivational and inflectional morphemes on song lyric in Maher Zain's "Forgive Me" album. Qualitative research is considered with structure and patterns (Littosseliti, 2010: 52). The writer elected this method because in this research used words, 
phrase, and sentence which was taken song lyric in Maher Zain's "Forgive Me" album in discussing data.

Data collection was important to determine the result of the study. According to Surakhmad (1985: 147), the procedure used to collect the data are: (1) Listening to the original songs of "Forgive Me" album of Maher Zain in several times to comprehend the lyrics; (2) Identifying the song lyrics to find the derivational and inflectional morphemes (3) Marking the derivational and inflectional morphemes found in the lyrics (4) Finding and classify all phrases that will be found in the lyrics. All of procedures above are used in this study.

After collecting the data, the writer was analyzing derivational and inflectional morpheme in English song lyrics on Maher Zain "forgive me" album. According to Meloeng (2004) stated that the data analyzing is organizing process in which the data are made in order in certain pattern, category and a unit of the basic explanation. In this study, the step of processing the data are as follows: (1) Selecting the derivational and inflectional morphemes found in the lyrics; (2) Coding the derivational and inflectional morphemes found in the lyrics; (3) Categorizing the lyrics based on two types of bound morpheme, or categorize whether the word lyric include the derivational or inflectional morphemes, (4) Tabulating the derivational and inflectional morphemes that will be found in the lyrics, (5) Drawing conclusion.

\section{RESULT AND DISCUSSION}

Based on the findings, the writer can describe the data for the following tables.

Table 1

Analysis of the Use of Derivational and Inflectional Morphemes in

"Number One For Me" Song Lyric

\begin{tabular}{|l|c|c|c|c|}
\hline No & Types of Morphemes & Function & Lyrics & Line \\
\hline 1. & Derivational & Adjective & Foolish & 1 \\
\hline 2. & Inflectional & Plural & Things & 2 \\
\hline 3. & Inflectional & Verb & Used & 2 \\
\hline 4. & Inflectional & Plural & Times & 5 \\
\hline 5. & Inflectional & Plural & Days & 6 \\
\hline 6. & Inflectional & Plural & Lies & 6 \\
\hline 7. & Inflectional & Verb & Sacrificed & 8 \\
\hline 8. & Derivational & Adjective & Undone & 10 \\
\hline 9. & Derivational & Adverb & Finally & 19 \\
\hline 10. & Inflectional & Verb & Learned & 24 \\
\hline 11. & Inflectional & Verb & Trying & 25 \\
\hline 12. & Inflectional & Verb & Taking & 28 \\
\hline 13. & Inflectional & Verb & granted & 28 \\
\hline 14. & Inflectional & Verb & knows & 32 \\
\hline
\end{tabular}

Based on the table 1, the writer can conclude that there are fourteen morphemes found in song lyrics of "number one for me", which consisted of three derivational morphemes and eleven inflectional morphemes. Then for the fuction of derivational and inflectional morphemes, the writer found four fuctions. They are adjective, plural, verb, and adverb.

Table 2

Analysis ofthe Use of Derivational and Inflectional Morphemes in "My Little Girl" Song Lyric

\begin{tabular}{|l|c|c|c|c|}
\hline No & Types of Morphemes & Functions & Lyrics & Line \\
\hline 1. & Inflectional & Verb & Blessing & 2 \\
\hline 2. & Inflectional & Plural & Eyes & 4 \\
\hline 3. & Derivational & Adjective & Unexplainable & 6 \\
\hline 4. & Inflectional & Verb & Feeling & 6 \\
\hline
\end{tabular}




\begin{tabular}{|l|c|c|c|c|}
\hline 5. & Inflectional & Verb & Thinking & 9 \\
\hline 6. & Inflectional & Verb & Makes & 9 \\
\hline 7. & Inflectional & Verb & Looking & 10 \\
\hline 8. & Derivational & Adjective & Grateful & 11 \\
\hline 9. & Inflectional & Verb & Having & 11 \\
\hline 10. & Inflectional & Verb & Shining & 18 \\
\hline 11. & Derivational & Adjective & Beautiful & 19 \\
\hline 12. & Inflectional & Plural & Steps & 24 \\
\hline 13. & Inflectional & Verb & Watching & 27 \\
\hline
\end{tabular}

Based on the table 2, the writer can conclude that there are thirteen morphemes found in song lyrics of "My Little Girl", which consisted of three derivational morphemes and ten inflectional morphemes. Then for the fuction of derivational and inflectional morphemes, the writer found three fuction. They are adjective, plural, and verb.

\section{Aable 3}

Analysis ofthe Use of Derivational and Inflectional Morphemes in "Forgive Me" Song Lyric

\begin{tabular}{|l|c|c|c|c|}
\hline No & Types of Morphemes & Functions & Lyrics & Line \\
\hline 1. & Inflectional & Verb & Keeps & 2 \\
\hline 2. & Inflectional & Noun & Dragging & 4 \\
\hline 3. & Inflectional & Verb & Thinking & 6 \\
\hline 4. & Inflectional & Verb & Comes & 6 \\
\hline 5. & Inflectional & Verb & Trying & 9 \\
\hline 6. & Derivational & Noun & Temptation & 9 \\
\hline 7. & Inflectional & Verb & Surrounding & 10 \\
\hline 8. & Inflectional & Verb & Forgiving & 11 \\
\hline 9. & Inflectional & Verb & Promised & 11 \\
\hline 10. & Inflectional & Verb & Standing & 18 \\
\hline 11. & Inflectional & Plural & Mistakes & 19 \\
\hline 12. & Inflectional & Verb & Committed & 24 \\
\hline 13. & Derivational & Noun & Prayer & 27 \\
\hline
\end{tabular}

Based on the Table 3, the writer can conclude that there are fourteen morphemes found in "forgive me" song lyrics, which consist of two derivational morphemes and twelve inflectional morphemes. Then for the fuction of derivational and inflectional morphemes, the writer found three fuction. They are noun, plural, and verb.

Table 4

Analysis ofthe Use of Derivational and Inflectional Morphemes in "One Big Family" Song Lyric

\begin{tabular}{|l|c|c|c|c|}
\hline No & Types of Morphemes & Function & Lyric & Line \\
\hline 1. & Inflectional & Plural & Similarities & 2 \\
\hline 2. & Inflectional & Plural & Eyes & 4 \\
\hline 3. & Inflectional & Plural & Lips & 4 \\
\hline 4. & Inflectional & Plural & Sometimes & 18 \\
\hline
\end{tabular}

Based on the table 4, the writer can conclude that there are four morphemes found in song lyrics of "one big family", which all of included inflectional morphemes. Then for the fuction of derivational and inflectional morphemes, the writer only found one function, it is plural.

Table 5

Analysis of the Use of Derivational and Inflectional Morphemes in "Paradise" Song Lyric

\begin{tabular}{|l|c|c|c|c|}
\hline No & Types of Morphemes & Function & Lyrics & Line \\
\hline
\end{tabular}


60 | Channing: English Language Education and Literature Vol. 5 No. 2 Oktober 2020 Halaman: 57-62

\begin{tabular}{|l|c|c|c|c|}
\hline 1. & Inflectional & Verb & Answered & 2 \\
\hline 2. & Inflectional & Verb & Wanted & 4 \\
\hline 3. & Inflectional & Verb & Perceived & 6 \\
\hline 4. & Inflectional & Verb & Feeling & 7 \\
\hline 5. & Inflectional & Verb & Knowing & 11 \\
\hline 6. & Inflectional & Verb & Pleased & 11 \\
\hline 7. & Inflectional & Noun & Seeing & 14 \\
\hline 8. & Inflectional & Plural & Things & 14 \\
\hline 9. & Inflectional & Verb & Hearing & 15 \\
\hline 10. & Inflectional & Plural & Refers & 15 \\
\hline 11. & Derivational & Adjective & Indescribable & 17 \\
\hline 12. & Inflectional & Plural & Times & 19 \\
\hline 13. & Inflectional & Plural & Days & 20 \\
\hline 14. & Inflectional & Plural & Minds & 22 \\
\hline 15. & Inflectional & Verb & Promised & 25 \\
\hline 16. & Inflectional & Verb & Dreaming & 28 \\
\hline
\end{tabular}

Based on the Table 5, the writer can conclude that there are sixteen morphemes found in song lyrics of "paradise", which consist of one derivational morpheme and fifteen inflectional morphemes. Then for the fuction of derivational and inflectional morphemes, the writer only found four fuction. They are adjective, noun, plural, and verb.

Table 6

Analysis of the Use of Derivational and Inflectional Morphemes in "Freedom" Song Lyric

\begin{tabular}{|c|c|c|c|c|}
\hline No & Types of Morphemes & Function & Lyrics & Line \\
\hline 1. & Inflectional & Verb & Gathered & 1 \\
\hline 2. & Inflectional & Plural & neighbors & 2 \\
\hline 3. & Inflectional & Plural & Friends & 2 \\
\hline 4. & Inflectional & Verb & Standing & 4 \\
\hline 5. & Inflectional & Verb & Holding & 4 \\
\hline 6. & Inflectional & Verb & Hands & 4 \\
\hline 7. & Inflectional & Verb & Giving & 10 \\
\hline 8. & Inflectional & Verb & Calling & 12 \\
\hline 9. & Inflectional & Verb & Fighting & 14 \\
\hline 10. & Inflectional & Verb & Being & 17 \\
\hline 11. & Inflectional & Plural & prisoners & 17 \\
\hline 12. & Inflectional & Plural & Homes & 17 \\
\hline 13. & Inflectional & Plural & Towards & 22 \\
\hline 14. & Inflectional & Noun & Getting & 23 \\
\hline 15. & Derivational & Noun & Closer & 23 \\
\hline 16. & Inflectional & Plural & Makes & 26 \\
\hline 17. & Inflectional & Verb & Shouting & 23 \\
\hline 18. & Inflectional & Verb & Demanding & 28 \\
\hline 19. & Inflectional & Verb & Breaking & 29 \\
\hline
\end{tabular}

Based on the Table 6, the writer can conclude that there are nineteen morphemes found in song lyrics of "forgive me", which consisted of one derivational morpheme and eighteen inflectional morphemes. Then for the fuction of derivational and inflectional morphemes, the writer three fuction. They are noun, plural, and verb.

Table 7

Analysis ofthe use of derivational and inflectional morphemes in "I Love You So" Song Lyric

\begin{tabular}{|l|c|c|c|c|}
\hline No & Types of Morphemes & Function & Lyrics & Line \\
\hline 1. & Derivational & Adverb & Solemnly & 4 \\
\hline
\end{tabular}




\begin{tabular}{|l|c|c|c|c|}
\hline 2. & Inflectional & Adverb & Pleasing & 8 \\
\hline 3. & Inflectional & Verb & Amazing & 13 \\
\hline 4. & Inflectional & Plural & Feels & 13 \\
\hline 5. & Derivational & Adverb & Finally & 14 \\
\hline 6. & Derivational & Adjective & Grateful & 20 \\
\hline 7. & Derivational & Adjective & Uncertainties & 22 \\
\hline 8. & Inflectional & Plural & Odds & 23 \\
\hline 9. & Inflectional & Plural & Days & 29 \\
\hline 10. & Inflectional & Plural & Nights & 29 \\
\hline 11. & Inflectional & Plural & Prayers & 30 \\
\hline
\end{tabular}

Based on the Table 7, the writer can conclude that there are ten morphemes found in song lyrics of "i love you so", which consist of four derivational morphemes and six inflectional morphemes. Then for the fuction of derivational and inflectional morphemes, the writer found four fuction. They are adverb, ,verb, plural, adverb, and adjective.

\section{CONCLUSION}

Based on discussion in chapter IV, the writer can conclude that there were eighty nine morphemes used in those seven song lyrics by Maher Zain's "forgive me" album. Which the eighty nine morphemes consist of 13 derivational morphemes and 76 inflectional morphemes. Furthermore, The function of derivational morphemes used on Maher Zain "forgive me" album, consist of function as adjective formation, verb formation, noun formation, and adverb formation. Then, the function of inflectional morphemes used on Maher Zain "forgive me" album, consist of third person singular, past tense, progressive, past participle, plural possessive, comparative, and superlative. The result above, it was taking from seven songs by Maher Zain's "forgive me" album, they are number one for me, my little girl, forgive me, one big family, paradise, freedom, and i love you so".

\section{REFERENCIES}

Aronoff, Mark and Fudeman, K. (2011). What is Morphology?. New Jersey: Wiley Blackwell.

Bauer, Laurie. 2012. Beginning Linguistics. United Kingdom : Palgrave Micmillan.

Bertoli-Dutra, P and Bissaco, C.M. (2006). In the Name of Love - Theme in U2 Songs.33 rd International Systemic Functional Congress.

Booij, Geert 2005. The Grammar of Words: An Introduction to Linguistic Morphology. New York: Oxford University Press.

Bull, V. 2008. Oxford Learner's Pocket Dictionary. New York : Oxford University Press. Carnie, Andrew. (2002). Syntax - a Generative Introduction. Oxford : Blackwell Published.

Cook, Vivian. (2012). The encyclopedia of applied linguistics. Oxford, UK: Wiley-Blackwell.

Fromkin, V., Rodman, R., \& Hyams, N. (2011). An Introduction to Language, Ninth Edition (International Edition). Boston, Massachusetts: Wadsworth Cengage Learning.

Haspelmath, Martin \& Andrea D. Sims. 2010. Understanding Morphology: 2nd Edition. London: Hodder Education.

Katamba, F., \& Stonham, J. (2006). Morphology, Second Edition. London, England: Red Globe Press. Kolanchery, G. (2015). Analytical Components of Morphology In Linguistics. Global English-Oriented Research Journal. 1(1), 161-166.

Kracht, M. (2007). Introduction to Linguistics. Los Angeles. LA: Hilgard Avenue.

Lieber, R. (2016). Introducing Morphology, Second Edition. New York, NY: Cambridge University Press.

Littosseliti, L. 2010. Research Method in Linguistics. London: Continuum International Publishing Group.

Moeliono, Anton M. 2007. Kamus Umum Bahasa Indonesia. Jakarta: Balai Pustaka.

Plag, I. (2003). Word-Formation in English. New York, NY: Cambridge University Press. 
62 Channing: English Language Education and Literature Vol. 5 No. 2 Oktober 2020 Halaman: 57-62

Risdianto, Faizal, S.S., M.Hum. 2013. An Introduction to Sociolinguistics. Salatiga : STAIN Salatiga Press.

Siahaan, Sanggam. 2008. Issues in Linguistic. First Edition. Yogyakarta : Graha ilmu. 